\title{
Urine carcinoembryonic antigen determination in urinary bladder bilharziasis predicts carcinoma in patients with premalignant lesions: observation of 43 cases in Egypt
}

\author{
G.M. SAIED ${ }^{1}$, W.H. EL-METENAWY ${ }^{1}$, M.S. ELWAN ${ }^{1}$ and N.R. DESSOUKI ${ }^{2 *}$ \\ ${ }^{1}$ Department of General Surgery and Radiation Oncology, Faculty of Medicine, Cairo University, Egypt \\ ${ }^{2}$ Department of General Surgery, St. Bernard's Hospital, Gibraltar, Egypt
}

\begin{abstract}
Both urinary bilharziasis and urothelial neoplasia are associated with increased production of tissue carcinoembryonic antigen (CEA). Urine and serum CEA were determined in 43 patients with urinary bladder carcinoma including 22 post bilharzial and 21 non-biharzial cases, in addition to 10 normal control cases. A significant increase was detected in both urine and serum CEA levels with bladder carcinoma compared to control cases. Urinary CEA was significantly elevated in $86 \%$ of bilharzial versus $62 \%$ in nonbilharzial bladder carcinoma. Only $10.5 \%$ of control cases had urinary CEA elevation. The mean urinary CEA in bilharzial was higher than that of nonbilharzial carcinoma, but the difference was not statistically significant. There was a definite relationship between urine CEA and the stage of malignancy; the higher the stage, the higher the level of urine CEA. No relationship could be detected between the stage of malignancy and serum CEA, or between the grades of malignancy and urine or serum CEA levels. In conclusion, urinary CEA is more useful than serum CEA in the early detection of bilharziasisassociated urothelial carcinoma.
\end{abstract}

Key words: Urinary bladder carcinoma, bilharziasis, CEA, Egypt

\section{Introduction}

Carcinoembryonic antigen (CEA) was originally thought to be a specific product of neoplasia derived from the endoderm. Accordingly and in view of the embryological origin of the bladder, urinary CEA was supposed to have a potential value in screening, diagnosis and follow up of patients suspected of having urothelial carcinoma (Hall et al., 1972). On the other hand, CEA has also been detected in other types of normal human tissue including prostate, uterus and spleen. Urinary CEA measurement and cytologic examination are two noninvasive procedures that have been compared and found to yield similar frequencies of positivism. Simultaneous performance of these two tests has been shown to increase the yield of positive results to $86 \%$ (Fraser et al., 1975). It has also been suggested that assay of urinary CEA might provide an alternative to urinary cytology for industrial screening of high risk population. In hospital practice, it is likely be useful alongside cytology and cystoscopy in primary diagnosis and routine follow up of patients with urothelial tumours after treatment to detect early recurrence. It has also been found to add to the information of $\mathrm{T}$ classification (Hall et al., 1973; Zimmerman et al., 1980). The finding that $\mathrm{T} 1$ and in situ carcinoma can yield raised values of CEA is of potential importance as it is this group of tumours which is difficult to detect by urinary exfoliative cytology (Neville et al., 1973).

Urinary CEA was first suggested to be particularly helpful to evaluate urothelial dysplasia Murphy et al. (1977). The assessment of urinary CEA in patients with bilharzial chronic cystitis, after control of infection provides a valuable screening test for premalignant lesions and malignant transformation (El-Metenawy et al., 1987). This agrees with the finding that bilharziasis in itself leads to increased urothelial production of CEA (Alsabti et al., 1979).

Raised serum CEA has been observed in association with invasive tumours or the presence of metastatic disease (Turner et al., 1977; Coombes et al., 1975). As regards CEA tissue level, it has been found in malignant vesical urothelium to be higher than in the control group, and to be much higher with infiltrating tumours (Moreno et al., 1997). Normalization of CEA level in follow up of treated cases has been observed by some workers, and is considered to mean successful management (Soma et al., 2004). On the other hand, local recurrence or multiple metastases are associated with elevated CEA (Kato et al., 2004).

Bilharzial carcinoma of the urinary bladder has been observed to represent a distinct clinicopathological entity different from nonbilharzial carcinoma (Gamal et al., 1987). The aim of this study was to assess the value of urinary and serum CEA in the diagnosis of carcinoma of

*Correspondence: Nazar R. Dessouki; E-mail: nazar_dessouki@doctors.org.uk 
the urinary bladder and to establish any difference between bilharzial and nonbilharzial carcinoma as regards production of CEA.

\section{Materials and Methods}

This study was conducted at Kasr EI-Aini University Hospital, Cairo, Egypt from April 2002 through April 2005. Forty three patients having proven carcinoma of the urinary bladder beside 10 control cases were enrolled in the study and categorized into three groups. Group I included 22 patients having bilharzial carcinoma; group II included 21 patients having nonbilharzial carcinoma while group III consisted of 10 normal controls with no infection or malignancy of the urinary tract or malignancy elsewhere. Radical cystectomy was done to patients of the first two groups.

For every case, urine and serum CEA were measured. Patients showing evidence of acute urinary tract infection were excluded. Samples of $10 \mathrm{ml}$ of midstream morning urine were collected. Samples with 5 pus cells or more / HPF were discarded. Five $\mathrm{ml}$ of blood were obtained from fasting individuals after at least 6 hours of stopping smoking. No additives or preservatives were necessary to maintain the integrity of the specimens. Grossly haemolysed samples were discarded. CEA was measured in both urine and serum by monoclonal enzyme immunoassay
(EIA) method using a commercially available kit from Abbott.

For patients with carcinoma of the urinary bladder, a detailed clinical history was taken. Patients with a positive history of bilharziasis were excluded from group II, but this was not sufficient to put them in group I. Clinical examination included staging according to the TNM system of UICC (El-Bolkainy et al., 1981). Cystocopic examination and biopsy were performed. Radical cystectomy was done for all cases and the specimens were examined for type and grade of malignancy, pathological staging and the presence or absence of associated bilharzial cystitis.

\section{Results}

There was a definite relationship between the stage of malignancy and the level of urine CEA, the higher the stage the higher the level of urine CEA (correlation coefficient $=0.35$ ). There was no relationship between the stage of malignancy and the level of serum CEA or between the grade of malignancy and the levels of both urine and serum CEA. The findings of CEA in urine and serum and the histological type and pathological stages in both bilharzial and nonbilharzial carcinoma of the urinary bladder are summarized in Table 1 and 2.

Table 1: CEA in urine and serum, histopathological type, grade of malignancy and pathological stage of bilharzial carcinoma of the urinary bladder

\begin{tabular}{|c|c|c|c|c|c|}
\hline $\begin{array}{c}\text { Case } \\
\text { No }\end{array}$ & $\begin{array}{c}\text { Urine } \\
\text { CEA(ng/ml) }\end{array}$ & $\begin{array}{c}\text { Serum } \\
\text { CEA (ng/ml) }\end{array}$ & $\begin{array}{c}\text { Histological } \\
\text { type }\end{array}$ & $\begin{array}{c}\text { Grade of } \\
\text { malignancy }\end{array}$ & $\begin{array}{c}\text { Pathological } \\
\text { staging }\end{array}$ \\
\hline 1 & 55 & 5 & Squamous cell & ॥ & $\mathrm{P} 2$ \\
\hline 2 & 47 & - & Squamous cell & I & $\mathrm{P} 2$ \\
\hline 3 & 9 & 17 & Squamous cell & i & $\mathrm{P} 1$ \\
\hline 4 & 72 & - & Squamous cell & I & $\mathrm{P} 2$ \\
\hline 5 & 40 & 7 & Squamous cell & ॥ & $\mathrm{P} 2$ \\
\hline 6 & 140 & 4 & Squamous cell & I & P3 \\
\hline 7 & 114 & 7 & Squamous cell & III & P3 \\
\hline 8 & 33 & 17 & Squamous cell & ॥ & P2 \\
\hline 9 & 10 & - & Squamous cell & I & $\mathrm{P} 2$ \\
\hline 10 & 13 & - & Squamous cell & I & P2 \\
\hline 11 & 4 & 35 & Squamous cell & i & $\mathrm{P} 1$ \\
\hline 12 & 14 & 8 & Squamous cell & II & P2 \\
\hline 13 & 85 & 0 & Transitional cell & III & $\mathrm{P} 2$ \\
\hline 14 & 105 & 0 & Squamous cell & $\|$ & P3 \\
\hline 15 & 100 & 5 & Transitional cell & $\|$ & $\mathrm{P} 2$ \\
\hline 16 & 70 & 1 & Squamous cell & I & P3 \\
\hline 17 & 28 & 0 & Squamous cell & $\|$ & P2 \\
\hline 18 & 270 & 9 & Aden carcinoma & III & P3 \\
\hline 19 & 135 & 35 & $\begin{array}{l}\text { Squamous cell } \\
\text { (verrucous type) }\end{array}$ & I & P3 \\
\hline 20 & 20 & 0 & Squamous cell & III & $\mathrm{P} 2$ \\
\hline 21 & 105 & 8 & Squamous cell & ॥ & P2 \\
\hline 22 & 165 & 0 & Transitional cell & ॥ & P3 \\
\hline
\end{tabular}

Mean urine CEA in bilharzial carcinoma: $75.09 \mathrm{ng} / \mathrm{ml}(\mathrm{SD}=64.26 \mathrm{ng} / \mathrm{ml})$

Mean serum CEA in bilharzial carcinoma: $5.03 \mathrm{ng} / \mathrm{ml}(\mathrm{SD}=5.41 \mathrm{ng} / \mathrm{ml})$ 
Table 2: CEA in urine and serum, histopathological type, grade of malignancy and pathological stage of non bilharzial carcinoma of the urinary bladder

\begin{tabular}{|c|c|c|c|c|c|}
\hline $\begin{array}{c}\text { Case } \\
\text { No }\end{array}$ & $\begin{array}{c}\text { Urine } \\
\text { CEA } \\
\text { (ng/ml) }\end{array}$ & $\begin{array}{c}\text { Serum } \\
\text { CEA } \\
\text { (ng/ml) }\end{array}$ & $\begin{array}{c}\text { Histological } \\
\text { Type }\end{array}$ & Grade & Stage \\
\hline 1 & 22 & 8 & Transitional & III & P3 \\
\hline 2 & 10 & 10 & Transitional & III & $\mathrm{P} 1$ \\
\hline 3 & 14 & - - & Transitional & III & $\mathrm{P} 2$ \\
\hline 4 & 30 & - - & Transitional & III & P3 \\
\hline 5 & 8 & 4 & Transitional & IV & $\mathrm{P} 2$ \\
\hline 6 & 26 & 3.5 & Transitional & III & $\mathrm{P} 2$ \\
\hline 7 & 160 & 2.5 & Transitional & III & P3 \\
\hline 8 & 17 & 3 & Transitional & III & P1 \\
\hline 9 & 13 & 3 & Transitional & III & P2 \\
\hline 10 & 3 & 5 & Transitional & III & $\mathrm{P} 1$ \\
\hline 11 & 165 & 0.5 & Transitional & III & $\mathrm{P} 2$ \\
\hline 12 & 135 & 0.5 & Anaplastic & IV & P3 \\
\hline 13 & 15 & 0.5 & Transitional & $\|$ & P2 \\
\hline 14 & 4 & 0.5 & Transitional & II & $\mathrm{P} 2$ \\
\hline 15 & 120 & 1 & Transitional & III & P3 \\
\hline 16 & 75 & 3 & Transitional & $\|$ & P1 \\
\hline 17 & 3 & 1 & Transitional & $\|$ & P1 \\
\hline 18 & 5 & 0 & Squamous & III & P3 \\
\hline 19 & 5 & 3 & Transitional & III & P2 \\
\hline 20 & 1 & 0 & Transitional & III & $\mathrm{P} 2$ \\
\hline 21 & 90 & 3 & Squamous & $\|$ & P1 \\
\hline
\end{tabular}

Mean for urine CEA in non-bilharzial carcinoma $=43.86 \mathrm{ng} / \mathrm{ml}(\mathrm{SD}=55.70 \mathrm{ng} / \mathrm{ml})$

Mean for serum CEA in non-bilharzial carcinoma $=2.74 \mathrm{ng} / \mathrm{ml}(\mathrm{SD}=2.68 \mathrm{ng} / \mathrm{ml})$

Mean urine in CEA in squamous cell carcinoma $=58.26 \mathrm{ng} / \mathrm{ml}(\mathrm{SD}=42.12 \mathrm{ng} / \mathrm{ml})$

Mean serum in CEA transitional cell carcinoma $=50.14 \mathrm{ng} / \mathrm{ml}(\mathrm{SD}=58.31 \mathrm{ng} / \mathrm{ml})$

Mean serum CEA in squamous cell carcinoma $=5.60 \mathrm{ng} / \mathrm{ml}(\mathrm{SD}=5.41 \mathrm{ng} / \mathrm{ml})$

Mean serum CEA in transitional cell carcinoma $=2.37 \mathrm{ng} / \mathrm{ml}(\mathrm{SD}=2.79 \mathrm{ng} / \mathrm{ml})$

Table 3: CEA in urine and serum, histopathological type, grade of malignancy and pathological stage of non bilharzial carcinoma of the urinary bladder

\begin{tabular}{ccc}
\hline Case No & Urine CEA $(\mathbf{n g} / \mathrm{ml})$ & Serum CEA ng/ml) \\
\hline 1 & 1 & 2 \\
2 & 0 & 2 \\
3 & 1 & 1.5 \\
4 & 0 & 2 \\
5 & 0.5 & 2.5 \\
6 & 1.5 & 1.5 \\
7 & 0 & 1 \\
8 & 2 & 1.5 \\
9 & 2 & 1.5 \\
10 & 1 & 1.5 \\
\hline
\end{tabular}

Mean serum CEA in squamous cell carcinoma $=5.60 \mathrm{ng} / \mathrm{ml}(\mathrm{SD}=5.41 \mathrm{ng} / \mathrm{ml})$

Mean serum CEA in transitional cell carcinoma $=2.37 \mathrm{ng} / \mathrm{ml}(\mathrm{SD}=2.79 \mathrm{ng} / \mathrm{ml})$

The proportion of cases having urine CEA above $10 \mathrm{ng} / \mathrm{ml}$ was $86 \%, 62 \%$ and $0 \%$ in groups I, II, and III, respectively. On the other hand, the proportion of cases having serum CEA above $5 \mathrm{ng} /$ $\mathrm{ml}$ was $39 \%, 10.5 \%$ and $0 \%$ in groups I, II and III, respectively. There was also a significant difference between urine CEA in cancer patients and in the controls (Table 3 ). There was no correlation between serum and urinary CEA values. 
Table 4: Difference between urine CEA in controls and cancer patients, in bilharzial and nonbilharzial and carcinoma; in squamous and transitional cell carcinoma

\begin{tabular}{lll}
\hline Presence of CEA & Parameter for statistical analysis & $P$-value \\
\hline In urine & Control and cancer patients & $P<0.01$ \\
& Bilharzial and non-bilharzial carcinoma & $P>0.5$ \\
In serum & Squamous cell carcinoma and transitional carcinoma & $P<0.1$ \\
& Control and cancer patients & $P<0.01$ \\
& Bilharzial and non-bilharzial carcinoma & $P>0.01$ \\
& Squamous cell carcinoma and transitional carcinoma & $P<0.05$ \\
\hline
\end{tabular}

Serum CEA levels were raised in 39 of the patients with bilharzial carcinoma of the urinary bladder and only in 10 of control cases. There was a significant difference $(P<0.01)$ between CEA in urine or serum in patients with cancer and the control (Table 4)

\section{Discussion}

Since CEA is present in the normal urothelium, destruction and regeneration of urothelial cells due to tumour or inflammation might release CEA into the urine (Tsugawa, 1992). It was suggested by some authors that elevated urinary CEA values, once infection is excluded, are specific to urothelial carcinoma, as the levels are normal in association with nonurothelial tumours such as hypernephroma, prostatic and colorectal carcinoma (Neville et al., 1973). Even if the plasma levels are raised, only when such tumours involve the urinary tract by infiltration do raised levels occur in urine. Urinary CEA-like activity was found to be increased in $61 \%$ of patients with transitional cell carcinoma of the bladder (Fraser et al., 1975).

Morning samples of urine were shown in one study to be more informative because of the benefit of overnight exposure of urine to the tumour (Coombes et al.1975). On the other hand, it has been observed that 24 hour urinary CEA is likely to be more informative being elevated in $81 \%$ of patients with active tumours (Murphy et al., 1977). In our study, CEA was measured in the morning samples of urine only.

Urinary infection was found to spoil the use of urinary CEA as a diagnostic procedure (Turner et al., 1977). The simple presence of bacteria in the urine irrespective of their identity or number has no influence on urinary CEA (Tailly et al., 1983). It is the inflammation of the urothelium that is responsible for the production and release of CEA. Therefore, only in the presence of symptoms and signs, and in the presence of pyuria, urinary tract infection is considered to exist. Infection was considered to be present if 5 leucocytes / HPF or more exist in the urine (Tsugawa, 1992). On the other hand, the effect of infection can largely be eliminated by routine use of midstream specimens of urine and its examination for pus cells and organisms (Hall et al., 1972). However, in this series patients showing symptoms and signs of acute urinary tract infection were completely excluded from the study.

Serum CEA levels have been found by some investigators to be of little value in the diagnosis of transitional cell carcinoma (Fraser et al., 1975). On the other hand, serum and urine CEA have been reported by other investigators to have less than enough of the diagnostic accuracy required for clinical diagnosis of urothelial cancer (Stefanovic et al., 1999). In this series, there were many patients with raised urinary CEA levels while serum CEA levels were within normal, but in two cases only serum CEA levels were raised with normal urinary CEA levels.

With nonmetastatic bladder carcinoma, plasma CEA levels in one study were raised only in $42 \%$ of the patients, but with the development of extravesical metastatic spread, the incidence of raised plasma CEA values increased to $85 \%$ (Neville et al., 1973). In a case report, CEA was found to be elevated with the development of adenocarcinoma in the reconstructed bladder following ileocystoplasty (Ishida et al., 1997). Some authors also stressed the use of plasma CEA in assessing response to chemotherapy in advanced bladder cancer (Cook et al., 2000). In this series, serum CEA levels were raised in $39 \%$ of patients with bilharzial carcinoma of the urinary bladder and in only $10.5 \%$ of control cases. This indicates that serum CEA is of little diagnostic value in carcinoma of the urinary bladder although there was a 
significant difference between the mean of serum CEA in patients with carcinoma and the controls. There were no documented cases with distant metastases but the patients with raised serum CEA levels in this series might have spread to the regional lymph nodes or have distant micrometastases elsewhere in the body.

Regarding the tumour stage, some authors have found a correlation between it and the level of CEA in urine, the higher the stage the higher the level (Fraser et al., 1975; Hall et al., 1973; Zimmerman et al., 1980; Guinan et al., 1974; Jonescu et al., 1976). In this study, a definite relationship was found between the stage of malignancy and the levels of urinary CEA in the urine; the higher the stage the higher the level of CEA. On the other hand, serum CEA was in another study found to increases with increasing extent of cancer (Fraser et al., 1975). On the contrary, other authors found no correlation (Zimmerman et al., 1980; Turner et al., 1977; Coombes et al., 1975. In this study, no relationship could be detected between the stage of malignancy and the level of serum CEA.

Many investigators have observed lack correlation between the grade of malignancy and urine CEA levels (Hall et al., 1972; Zimmerman et al., 1980; Neville et al., 1973; Murphy et al., 1977; Tailly et al., 1983; Collen et al., 1979; Wahren, 1978). However, others have advocated that the less differentiated the tumour, the higher is the level of CEA in the urine (Fraser et al., 1975). In our study, no correlation could be detected between the urinary CEA levels and the different grades of malignancy.

The levels of urinary CEA in this study in bilharzial carcinoma were higher than the levels in nonbilharzial carcinoma, though the difference was insignificant. This difference may be attributed to the associated chronic cystitis which is always present in bilharzial carcinoma as chronically stimulated urothelium forms CEA at an increased rate, and therefore increased release of CEA in the urine occurs (Zimmerman et al., 1980; Jautzke \& Altenaehr, 1982). It has also been found by some authors that in premalignant bilharzial lesions, CEA in the urine reaches levels as high as those encountered in frank bladder malignancy (ElMetenawy et al. 1987). These premalignant lesions in association with bilharzial carcinoma may lead to the increase in CEA production. The other proposed cause for this difference is the tumour mass, as bilharzial carcinoma tends to be more bulky (Gamal \& Khalil, 1987), and according to some authors, CEA in the urine increases with the increase in the size of the tumour (Neville et al., 1973; Tailly et al., 1983; Guinan et al., 1974; Wahren, 1978). This difference is not due to the histopathological difference between bilharzial and nonbilharzial carcinoma as no difference could be detected between urinary CEA in squamous cells carcinoma and transitional cell carcinoma in this study.

In conclusion, estimation of urine CEA can be useful in the early detection of carcinoma of the urinary bladder among high risk people, particularly if provoked by bilharziasis. It adds more data to the staging of tumours, and hence to the prognosis after treatment.

\section{References}

Alsabti, E.K. \& Kamel, A. (1979) Carcinoembryonic antigen (CEA) in patients with malignant and non-malignant diseases. Neoplasma 26, 603-609.

Collen, S.Er.A., Gullberg, B., Johansson, B.G., Lindberg, L.G. \& Olsson, A.M. (1979) CEA in urine in patients with urothelial Carcinoma. Scandinavian Journal of Urology and Nephrology 13, 149.

Cook, I.S., Huddart, RA., Jay, G., Norman, A., Dearnaley, D.P. \& Horwich, A. (2000) The utility of tumour markers in assessing the response to chemotherapy in advanced bladder cancer. British Journal of Cancer $\mathbf{8 2}$, 1952-1957.

Coombes, G.B., Hall, R.R., Laurence, D.J.R. \& Neville, A.M. (1975) Urinary carcinoembryonic antigen (CEA) like molecules and urothelial malignancy: a clinical appraisal. British Journal of Cancer 31,135.

El-Bolkainy, M.N., Tawfik, H.N. \& Kamel, L.A. (1981)Histopathologic classification of carcinomas in the schistosomal bladder in detection of bladder cancer associated with schistosomiasis. In: N.N. El-Bolkainy \& K.W. Chu, editors. Cairo, Egypt: Al-Ahram Press; p. 106.

El-Metenawy, W.H., El-Razky, Y.S., Mahfouz, S., Shukry, I., Abdin, M., Hashem, T., Hashem, B. \& El-Haddad, S. (1987)Value of urinary carcinoembryonic antigen (CEA) in the early detection of malignant transformation of bilharzial bladder. Journal of Egypt National Cancer Institute 3, 195.

Fraser, R.A., Ravry, J., Segura, J.W. \& Go, V.L.W. (1975) Clinical evaluation of urinary and 
serum carcinoembryonic antigen in bladder cancer. Journal of Urology 114, 226.

Gamal, G.M. \& Khalil, A. (1987) Rectosigmoid cystoplasty after cystectomy for bilharzial bladder carcinoma: A preliminary report. Egypt Journal of Surgery 6, 29

Guinan, P., John, T., Sadoughi, N., Ablin, R.J. \& Bush, I. (1974) Urinary carcinoembryonic like antigen level in patients with bladder carcinoma. Journal of Urology 111, 350.

Hall, R.R., Laurence, D.J.R., Darcy, D., Stevens, U., James, R., Roberts, S. \& Neville, A.M. (1972) Carcinoembryonic antigen in the urine of patients with urothelial carcinoma. British Medical Journal 3, 609.

Hall, R.R., Laurence, D.J.R., Neville, A.M. \& Wallace, D.N. (1973) Carcinoembyronic antigen and urothelial carcinoma. British Journal of Urology 45, 88.

Ishida, T. \& Koizumi, H. (1997) A case of adenocarcinoma of the reconstructed bladder following ileocystoplasty. [In Japanese]. Nippon Hinyokika Gakkai Zasshi 88,439442.

Jautzke, G. \& Altenaehr, E. (1982) Immunohistochemical demonstration of carcinoembryonic antigen CEA and its correlation with grading and staging on tissue sections of urinary bladder carcinomas. Cancer 50, 2052.

Jonescu, G., Ronas, N.A., Jonescu, L., Bennett, S., Tannenbaun, M., Veema, R.J. \& Lattiner, J.K. (1976) Carcinoembryonic antigen and bladder carcinoma. Journal of Urology $\mathbf{1 1 5}$, 46.

Kato, S., Yasuda, M., Nakano, M., Ehara, H., Ishihara, T., Degushi, T., Sakata, Y., Mori, H. \& Shimokawa, K. (2004) Superficial urothelial carcinoma of ureter with elevated serum CA19-9 and CEA. [In Japanese]. Hinyokika Kiyo 50, 99-102.

Moreno Sierra, J., Chicharro Almarza, G.J., Torronteras Santiago, J.M., Ortega Heredia, M.D., Maestro De las Casas, M.L., Silmi Moyano A. \& Resel Estevez, L. (1997) Advances regarding tumour markers in bladder cancer. [In Spanish]. Acta Urologia Espania 21,195-205.

Murphy, W.M., Vandevoorde, J.P., Rao, I.K. \& Soloway, N.S. (1997) The clinical value of urinary carcinoembryonic antigen like substances in urothelial cancer. Journal of Urology 118, 806.

Nagao, K., Hisatomi, H., Hirata, H., Yamamoto, S., Hikiji, K., Yamamoto, M. \& Kanamaru,
T. (2002) Expression of molecular marker genes in various types of normal tissue: implication for detection of micrometastases. International Journal of Molecular Medicine 10, 307-310.

Neville, A.M., Nery, R., Hall, R.R., Turberville, C., \& Laurence, D.J.R. (1973)Aspects of the structure and clinical role of the carci $\neq$ noembryonic antigen CEA and related macromolecules with particular reference to urothelial carcinoma. British Journal of Cancer 28, Suppl.1, 198.

Soma, I., Hasuike, Y., Hayashi, N., Fukuchi, N., Izawa, H., Yoshida, T., Ebisui, C., Sakita, I., Fujimoto, T., Koshino, T. \& Izumiyama, K. (2004) A case report- efficacy of combination therapy to unresectable advanced gall bladder carcinoma- palliative operation, hepatic arterial infusion therapy, and radiation therapy. [In Japanese]. Gan To Kagaku Ryoho 31, 443-449.

Stefanovic, V., Mitic-Zlatkovic, M., Ignjatovic, I., Vlajkovic, M. \& Scepovic, Z. (1999) Tissue polypeptide antigen and carcinoembryonic antigen lack diagnostic accuracy in urothelial carcinoma. International Urology and Nephrology 31, 443-449.

Tailly, G., Cornellssen, M., Verfecken, R.L., Verduyn, H., Devos, P. \& De Roo M. (1983) Urinary carcinoembryogenic antigen (CEA) in the diagnosis and follow-up of bladder carcinoma. British Journal of Urology 55, 501.

Tsugawa AM. (1992) Immunological and biochemical characterization of urinary carcinoembryonic antigen and its clinical significance. Nippon - Hinyokika Gakkaizasshi 83, 1600.

Turner, A.G., Carter, S., Higgins, E., Glashan, R.W., Neville, R.W. \& Neville, A.M. (1977) The clinical diagnostic value of the carcinoembryonic antigen (CEA) in haematuria. British Journal of Urology 49, 61-66.

Wahren, B. (1978) Cellular content of carcinoembryonic antigen in urothelial carcinoma. Cancer 42, 1533.

Zimmerman, R., Wahren, B. \& Edsmyr, F. (1980) Assessment of serial CEA determinations in urine of patients with bladder carcinoma. Cancer 46,1802. 